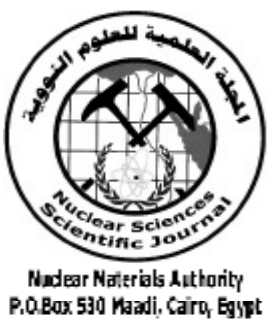

ISSN 2314-5609

Nuclear Sciences Scientific Journal

8, 79- 97

2019

http://www.ssnma.com

\title{
MINERALOGY, CHEMISTRY AND RADIOACTIVITY OF THE ANOMALOUS QUARTZ VEIN ACCOMPANYING THE WESTERN SHEAR ZONE OF RAS ABDA GRANODIORITE, NORTH EASTERN DESERT, EGYPT
}

\author{
ABD ELMOEZ A. SADEK; WAFAA. H. SALEH and EHAB K. ABU ZEID \\ Nuclear Materials Authority, P. O. Box 530, El-Maadi, Cairo, Egypt
}

\begin{abstract}
The quartz vein cutting the granodiorite of Ras Abda, along the western shear zone, exhibits high radioactive potentiality (up to $3000 \mathrm{ppm}$ for Th and $1600 \mathrm{ppm}$ for $\mathrm{U}$. The microscopic investigation of the quartz vein revealed that it is composed mainly of quartz and iron oxides enclosing squadrons of the accessory minerals. Granitic fragments are corroded and digested from the wall-rock affecting the chemical composition of the studied rock. Chemically, it is characterized by low alumina and medium potassium contents with peralkaline affinity. It is also characterized by high concentrations of the trace elements ( $\mathrm{Zr}>10000, \mathrm{Nb} 3481, \mathrm{Y} 8621$, U 903 and Th $2340 \mathrm{ppm}$ ) and the total rare earth elements (up to $24246 \mathrm{ppm}$ ) specially the HREEs with very low degree of fractionation in the melt (0.014) and in turn, high degree of fractionation in the accessory minerals.

The mineralogical investigation using ESEM and XRD techniques revealed the minerals are responsible for the radioactivity in the anomalous rock such as zircon, thorite, uranothorite and $\mathrm{Nb}-\mathrm{Ta}$ minerals (columbite, euxenite and uranopolycrase).

Experimental work in this study agreed with the previous experiments and concluded that metamictization is attributed to the heat of self-annealing that responsible for transformation of U-euxenite to metamictized euxenite and transformation of Ti-U-euxenite to metamictized uranopolycrase.

The present study concluded that the studied quartz vein originated from silicic magma rich in the trace and rare earth elements; hence it is considered as good hostile for the radioelements and possesses high radioactive potentiality.
\end{abstract}

\section{INTRODUCTION}

Ras Abda area is located at West of Safaga City, at the beginning of Wadi Ras Al Barud. It lies between Lat $26^{\circ} 42^{\prime}$ and $26^{\circ} 46^{\prime} \mathrm{N}$ and Lon $33^{\circ} 45^{\prime}$ and $33^{\circ} 48^{\prime} \mathrm{E}$. This area is intersected by W. Ras Abda and W. Abu Hadida. W. Ras Abda run through the middle part of the area and extended to about $10 \mathrm{~km}$ in the ENE direction. The exposed rock units in the area comprise older granitoids, younger gabbros and younger granites. The rocks of the area are intersected with numerous dikes ranging from acidic to basic in composition. They are emplaced along regional fractures of North- south, NW-SE, East-West and NE-SW trends. The acidic dikes have usually the greatest length may exceed $2 \mathrm{~km}$ with widths varying from 0.5 to $5 \mathrm{~m}$. El Hadary et al., (2015) studied the geology, petrology and mineralogy of Ras Abda area concerned the area of study and classified the granites of Ras Abda into granodiorite, monzogranite 
and alkali-feldspar granite. They localized an anomalous site at the western shear zone cutting the granodiorite

The present work concerns with the anomalous rocks cropping along the western shear zone of Ras Abda granodiorite located at the intersection of latitude $26^{\circ} 43^{\prime}$ and longitude $33^{\circ} 47^{\prime}$. Silicic magma is a significant source for the acidic rocks, ascending along the shear zones and spreads through the fractures as quartz vein cutting the granodiorite. This work aims to study this anomaly comprising its geologic setting, petrography, chemistry and mineralogy. Although, it is a limited exposure but it attains its significance due to its high content of uranium proved by the field measurements and considered as good host for uranium, thorium and rare earth elements.

\section{GEOLOGY AND PETROGRAPHY}

Ras Abda monzogranite is intruded by alkali-feldspar granite along a giant fault plane that extends N35E and separates the monzo- granite into two parts east and west the fault plane (Fig.1). Monzogranites intrude the older granite separating the granodiorite into two parts to northern and southern one. The studied rock is located in the southern block of granodiorite (west to the studied area) along the E-W shear zone concordant with Wadi. Ras Abda. The width of shear zone is more than $40 \mathrm{~cm}$ filled completely by the anomalous rock that extends in the fractures dominating the surrounding granodiorite (Fig.2). Megascopically, Ras Abda granodiorite is medium-grained size ranging in color from gray to reddish gray, especially near the shear zone resulting of alteration processes such as sericitization and hematitization (El Hadary, 2015).

The anomalous rock covering the shear zone is acidic rock characterized by massive appearance and black color patched by pinkcolored rock fragments of granitic composition (Fig.3). The surrounding granite itself is dominated by black-colored veinlets (Fig.4). The mechanism of formation of the studied

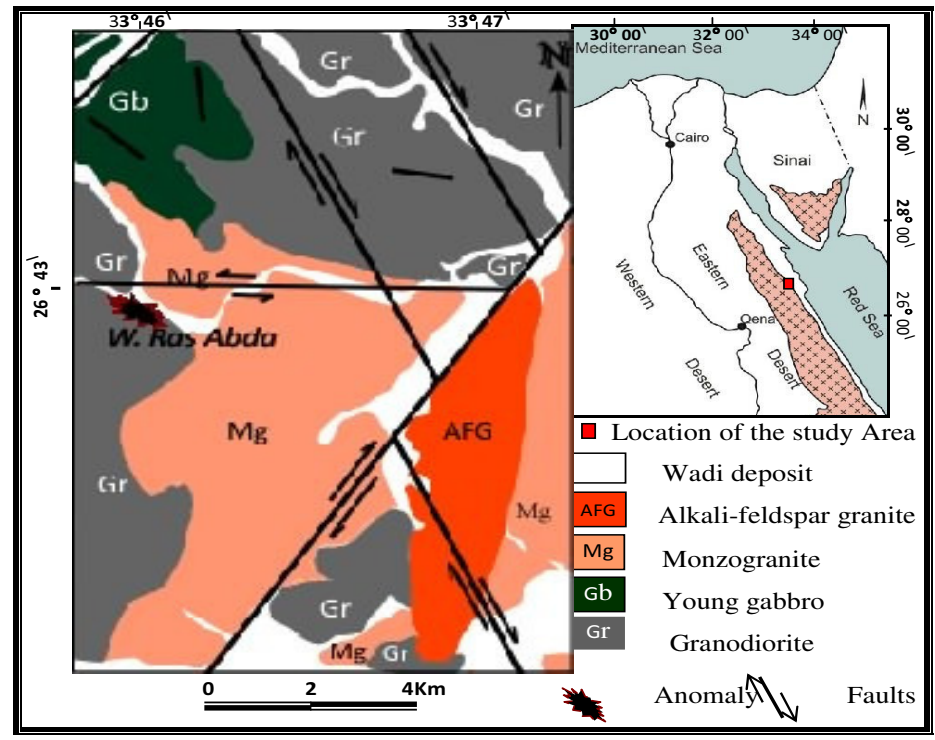

Fig.1:Geological map for W. Ras Abda area, Central Eastern Desert, Egypt (Modified after El Hadary et al., 2015) 


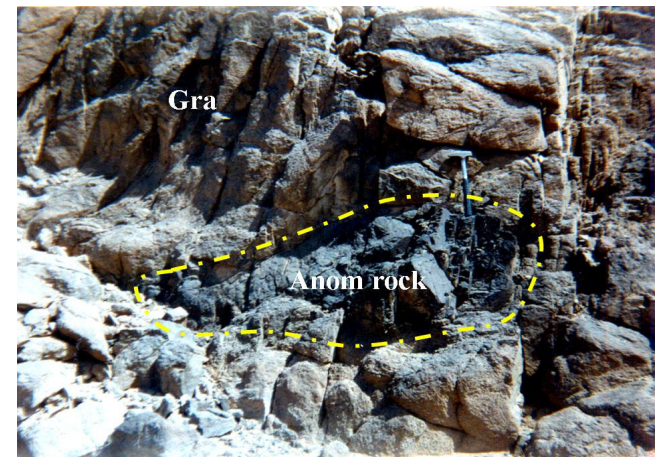

Fig. 2:Field photograph of the anomalous rock (Anom) surrounded by Ras Abda hematitized Granodiorite (Gra), western shear zone

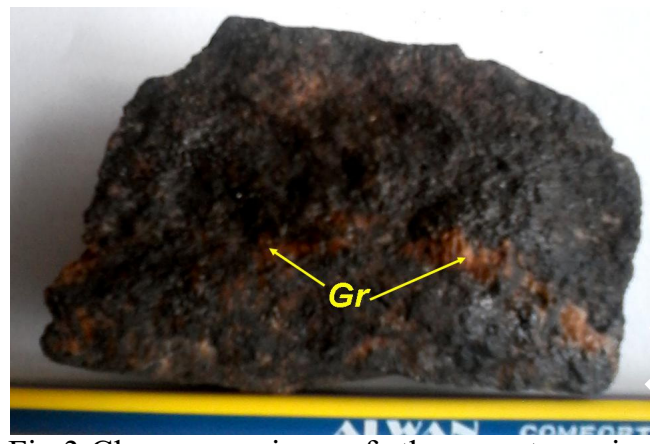

Fig.3:Close up view of the quartz vein enclosing granitic fragments $(G r)$ from the wall rock

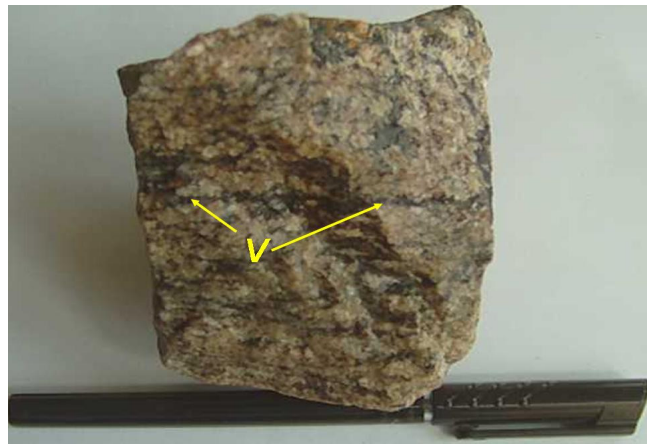

Fig.4: Close up view of Ras Abda granodiorite enclosing black veinlets $(V)$ squeezed from the silicic magma rock could be explained by a structural pattern (modal) where the silicic magma ascends along the shearing plane corroding the wall rock and captures the granitic fragments (Fig.5). Finally, this magma is extruded (surface or near surface) forming the studied rock and squeezed in the surrounding granite through the fractures forming the black veinlets.

The microscopic investigation of Wadi Ras Abda granodiorite hosting the anomaly quartz vein revealed that it is mainly composed of plagioclase and quartz with some biotite. Biotite is intensively altered to chlorite of penninite type; its titanium content is excluded as secondary titanite mostly associating the penninite (Fig.6). Accessory minerals are mainly apatite (Fig.7) and zircon in addition to the secondary titanite. Zircon occurs as well-formed zoned crystals included in quartz; and enclose occasionally opaque inclusions (Fig.8). Rare crystals of allanite are also present associating

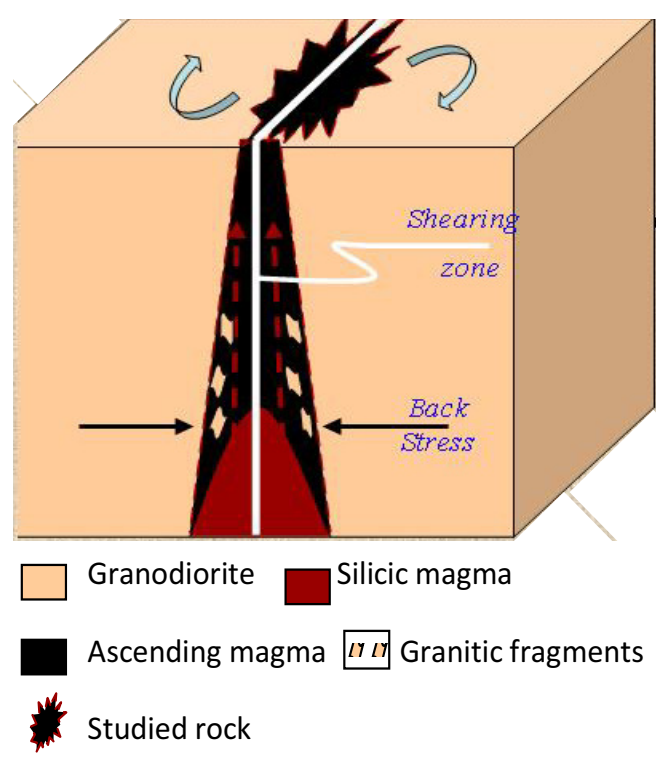

Fig.5:Sketched pattern showing ascending of the silicic magma and formation of the studied rock 


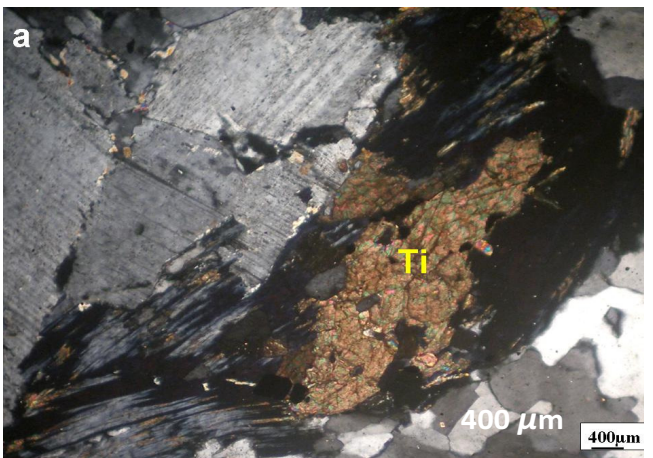

Fig.6:Photomicrograph of the granodiorite surrounding the anomalous rock showing: secondary titanite $(\mathrm{Ti})$ associating penninite, XPL

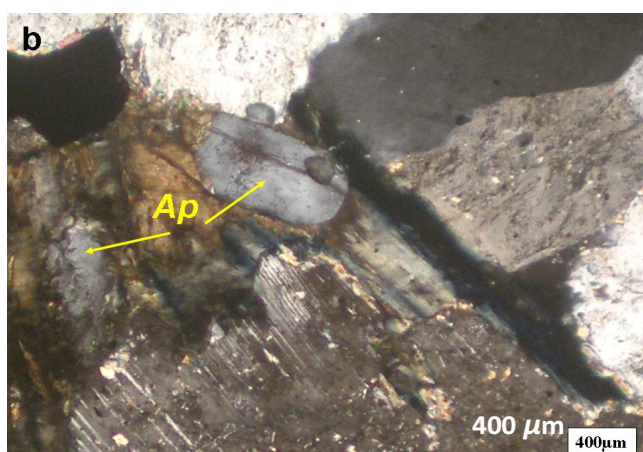

Fig.7:Anhedral crystals of apatite $(A p)$ associating plagioclase, XPL

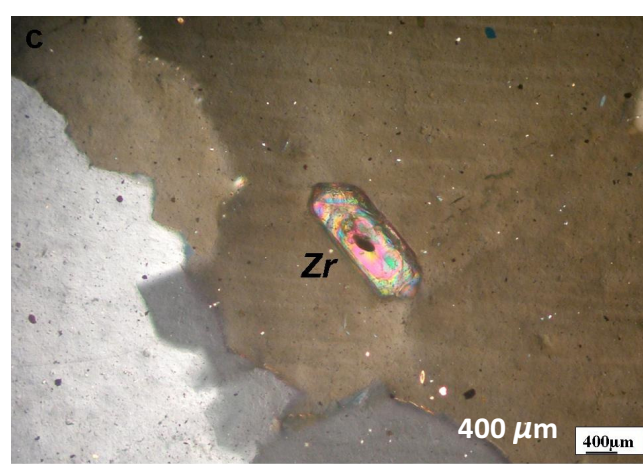

Fig.8:Well-formed crystal of zircon $(\mathrm{Zr})$ included in quartz, XPL the opaque minerals (Fig.9).

Microscopic examination of the rock under consideration (anomalous quartz vein) revealed that it is composed mainly of fine to medium quartz crystals (length $1.2 \mathrm{~mm}$ and width $0.5 \mathrm{~mm}$ ). They are slightly elongated referring to a weak back stress generated from the wall rock (Fig.10) and mostly coated by iron oxides. The rock encloses rock-fragments of granitic composition, (plagioclase, quartz and rare potash feldspars).

Mostly, the granodiorite stained by iron oxides resembling the Ras Abda granodiorite and most propably captured from the wall rock. Quartz of the rock fragment is coarser (3mm) and encloses fine crystals of zircon (Fig.11). The studied rock contains immense amount of the accessory minerals in the form of squadrons associating the opaque minerals; they are mainly zircon and euxenite. Zircon occurs as well-formed prismatic crystals with wide variability in the dimensions. Most of zircon crystals are partially or completely metamictized (Fig.12) including orange inclusions of thorite (Fig.13). Uranopolycrase is also present as well-formed bipyramidal crystals partially metamictized (Fig.14) enclosing the same orange inclusions of thorite (Fig.15) as confirmed by EDX analysis.

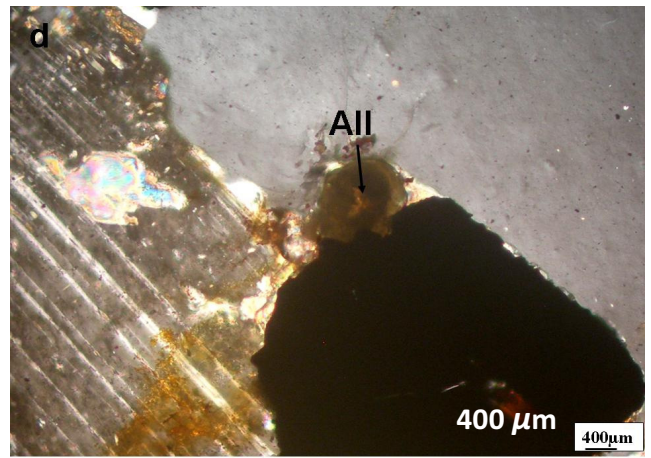

Fig.9: Anhedral crystal of allanite (All) with masked interference colors, XPL 


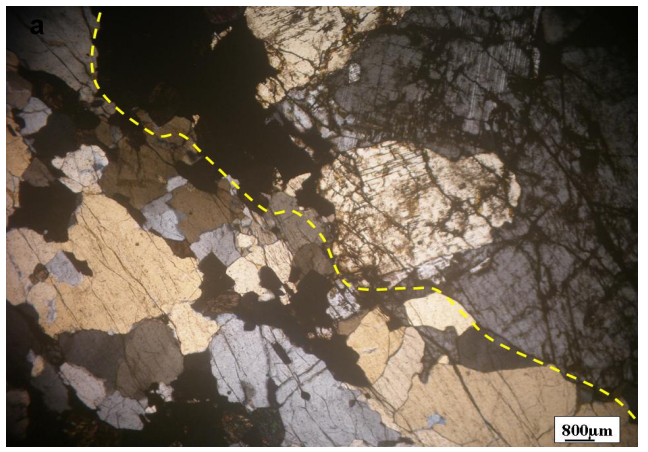

Fig.10:Boundary of the granitic fragment (dashed line) in contact with the finer quartz, XPL

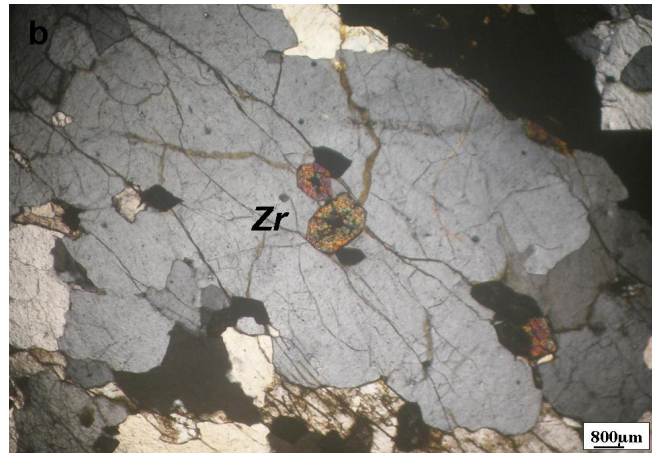

Fig.11:Quartz of the granitic fragment corroded by the finer quartz and encloses zircon, XPL

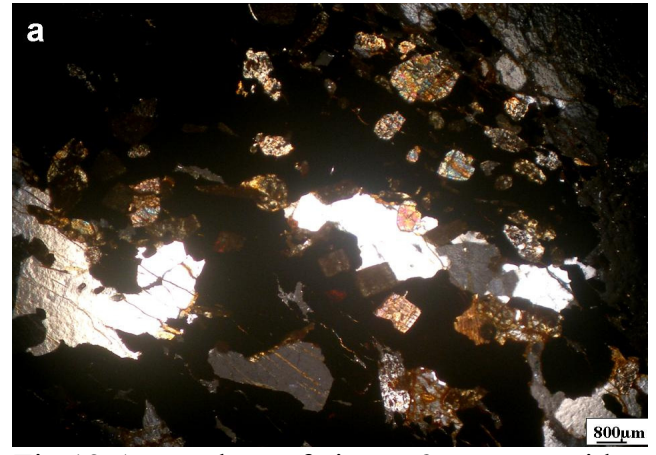

Fig.12:A squadron of zircon \& opaque with quartz,XPL

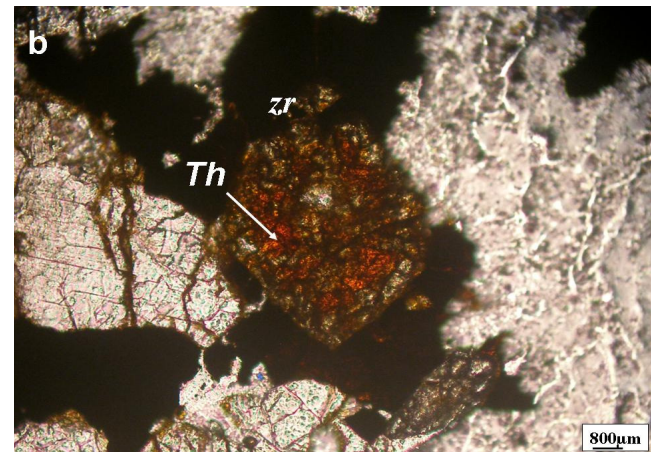

Fig.13:Zircon crystal with thorite inclusion, PPL.

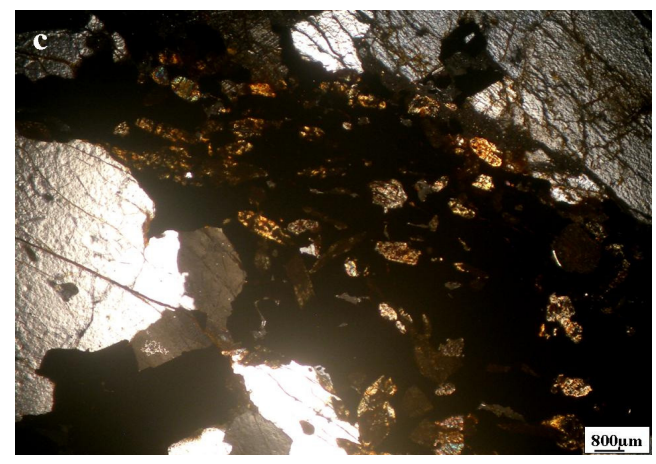

Fig.14:A squadron of polycrase, zircon \& opaque, XPL

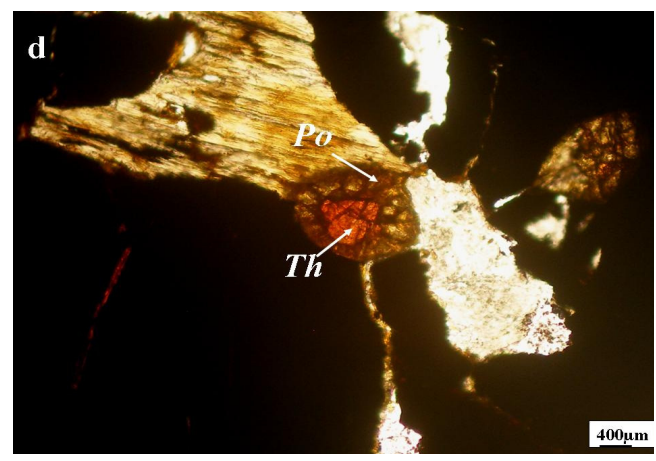

Fig.15: Polycrase crystal with thorite inclusion, PPL. 


\section{CHEMICAL CHARACTERISTICS}

The major oxides are determined by using wet chemical analytical methods (Shapiro and Brannock, 1962). The trace elements are determined by X-ray fluorescence technique using the Philips X-ray spectrometer (X-Unique II). U determined by the oxidimetric titration process after the reduction uses a standard solution of ammonium metavanadate (Mathew et al., 2009), after a priors uranium reduction step using ammonium ferrous sulphate. In this procedure, di-phenyl sulphonate has been used as indicator where color change to slightly violet red color. Concerning thorium in aqueous solution, a visible-ultra violet spectrometer was used for its quantitative analysis using $0.05 \%$ arsenaza III at $650 \mathrm{~nm}$, (Maschzinco, 1986). The chemical analyses were carried out in the NMA Labs.

The studied anomalous quartz vein is characterized by average silica content $(60.86 \%)$ accompanied with very low alumina content (average 4.34\%) and low potassium content $(1.42 \%)$. The other oxides $\left(\mathrm{TiO}_{2}, \mathrm{FeO}, \mathrm{Fe}_{2} \mathrm{O}_{3}\right.$, $\mathrm{MnO}, \mathrm{MgO}, \mathrm{CaO}, \mathrm{Na}_{2} \mathrm{O}_{3}$ and $\mathrm{P}_{2} \mathrm{O}_{3}$ ) are relatively high. Loss of ignition (L.O.I) is relatively high with an average 3.7 , correlating with the high contents of iron and magnesium oxides (Table1).

Plotting of the silica contents versus some major oxides for the rock under consideration ( 8 rock samples and their average) exhibits negative correlation with $\mathrm{Al}_{2} \mathrm{O}_{3}$ and $\mathrm{CaO}$ following the normal trends of fractional crystallization. The other oxides (total alkalis, $\mathrm{Fe}_{2} \mathrm{O}_{3}{ }^{\mathrm{t}}$, $\mathrm{MgO}$ and $\mathrm{MnO}$ ) exhibit scattering and irregular relations with silica referring to mixing of the magma caused by assimilation of the wall rock (Figs.16-21). Bowen (1928) stated that the latent heat of crystallization during fractional crystallization can provide sufficient thermal energy to consume the wall-rock. O'Hara (1980) argued that this contamination may cause minor change in composition of the liquid.

Plotting of the analyzed samples on the classification diagram of Jill (1981) clarified that the studied rock is acidic rock characterized by low to medium potassium content (Fig.22). Plotting $\mathrm{Al}_{2} \mathrm{O}_{3}$ versus the total alkalis and $\mathrm{CaO}$ on the ternary diagram of Petro, et al., (1979) clarified that the alumina content is rather low relative to the total alkalis giving the rock its alkaline affinity. Most of these samples plot in the field of peralkaline except one sample plots in the peraluminous field resulting from its low potassium content (0.48\%), (Fig.23). Plotting Ba/Nb versus $\mathrm{SiO}_{2}$ the ratio revealed that the fractional crystallization is completed with absence of the alkali feldspar, where the plotted samples followed the trend of fractional crystallization without alkali feldspars (Fig.24). Trace elements concentrations are mostly very high except $\mathrm{Rb}$ and $\mathrm{Cu}$ which are undetected (Table1). Normalization of the trace elements by chondrite values showed that the studied rock is characterized by enrichment of $\mathrm{Ba}, \mathrm{Sr}, \mathrm{Y}, \mathrm{Zr}, \mathrm{Nb}, \mathrm{Th}$, $\mathrm{U}, \mathrm{pb}$ and $\mathrm{Zn}$ and depletion of $\mathrm{Rb}, \mathrm{Ni}$ and $\mathrm{Cr}$, while V approaches the line of unity (Fig.25).

\section{Rare Earth Elements}

Rare earth elements of the studied rock ( 8 samples) are analyzed by Induced Couple Plasma Spectrometer (ICP) in the labs of Egyptian Atomic Energy Authority. Generally, the rock is characterized by high content of rare earth elements (up to $24246 \mathrm{ppm}$ ) that are attributed to the presence of the REE-bearing accessory minerals as proved by EDX analyses as zircon, uranothorite and $\mathrm{Nb}$-Ta minerals. The studied rock is characterized by LREEs (average 3328 ppm) lower than HREEs (17807 ppm), (Table 2). (HREEs are six times as LREEs). Ce exhibits strong variability in its concentrations (up to $1653 \mathrm{ppm}$ ) proving that it is accommodated in the accessory minerals, while $\mathrm{Nd}$ has the highest concentrations compared to the other LREEs in all samples (up to $2297 \mathrm{ppm}$ ). $\mathrm{Eu}$ is completely absent because of the complete absence of plagioclase from the melt.

The REEs concentrations are normalized to chondrite (Taylor and McLennan, 1985) and 
MINERALOGY, CHEMISTRY AND RADIOACTIVITY OF THE ANOMALOUS 85

Table 1: Chemical analyses of major oxides (wt\%) and trace elements (ppm) for the anomalous quartz vein of Wadi Ras Abda

\begin{tabular}{|c|c|c|c|c|c|c|c|c|c|}
\hline $\begin{array}{l}\text { Sample } \\
\text { No. }\end{array}$ & $\mathbf{R 1}$ & $\mathbf{R 2}$ & $\mathbf{R 3}$ & $\mathbf{R 4}$ & $\mathbf{R 5}$ & R6 & R7 & $\mathbf{R 8}$ & Av. \\
\hline \multicolumn{10}{|c|}{ Major Oxides \% } \\
\hline $\mathrm{SiO}_{2}$ & 63.00 & 60.00 & 64.4 & 66.50 & 57.2 & 60.25 & 58.1 & 57.4 & 60.86 \\
\hline $\mathbf{T i O}_{2}$ & 1.50 & 1.79 & 1.89 & 1.5 & 2.3 & 2.4 & 1.65 & 2.16 & 1.90 \\
\hline $\mathrm{Al}_{2} \mathrm{O}_{3}$ & 3.00 & 3.5 & 3.32 & 3.5 & 4.5 & 5.7 & 5.8 & 5.4 & 4.34 \\
\hline FeO & 7.79 & 8.65 & 9.34 & 8.72 & 8.88 & 9.02 & 7.77 & 7.42 & 8.45 \\
\hline $\mathrm{Fe}_{2} \mathrm{O}_{3}$ & 4.34 & 4.76 & 4.11 & 4.31 & 5.13 & 5.02 & 5.64 & 5.3 & 4.83 \\
\hline MnO & 0.87 & 0.96 & 1.04 & 0.97 & 1.09 & 1.56 & 1.43 & 1.38 & 1.16 \\
\hline MgO & 7.00 & 7.3 & 3.98 & 3.73 & 4.5 & 7.61 & 5.3 & 6.28 & 5.71 \\
\hline $\mathbf{C a O}$ & 2.00 & 3.09 & 1.12 & 1.3 & 2.6 & 1.12 & 2.31 & 2.51 & 2.01 \\
\hline $\mathbf{N a} \mathbf{a}_{2} \mathbf{O}$ & 5.33 & 5.44 & 4.15 & 4.05 & 5.6 & 3.34 & 4.33 & 5.00 & 4.66 \\
\hline $\mathbf{K}_{2} \mathbf{O}$ & 1.50 & 1.42 & 0.88 & 1.5 & 2.1 & 0.48 & 1.59 & 1.87 & 1.42 \\
\hline $\mathbf{P}_{2} \mathbf{O}_{5}$ & 1.50 & 1.4 & 1.1 & 0.42 & 1.4 & 0.5 & 2.6 & 0.69 & 1.20 \\
\hline L.O.I & 2.60 & 2.6 & 4.39 & 3.7 & 4.7 & 3.0 & 3.57 & 5.00 & 3.70 \\
\hline Total & 100.43 & 100.9 & 99.72 & 100.2 & 100.0 & 100. & 100.09 & 100.41 & 100.22 \\
\hline \multicolumn{10}{|c|}{ Trace elements (ppm) } \\
\hline $\mathbf{B a}$ & 4048 & 6450 & 3958 & 4617 & 4809 & 5666 & 4515 & 4808 & 4859 \\
\hline $\mathbf{R b}$ & ud & ud & ud & ud & ud & ud & ud & ud & ud \\
\hline $\mathbf{C u}$ & ud & ud & ud & ud & ud & ud & ud & ud & ud \\
\hline Sr & $\mathbf{8 1 3}$ & 870 & 665 & 740 & 1222 & 959 & 764 & 754 & 848 \\
\hline $\mathbf{Y}$ & 8506 & 8988 & 7020 & 7854 & 10000 & 10000 & 7918 & 8685 & 8621 \\
\hline $\mathbf{Z r}$ & $>10000$ & $>10000$ & $>10000$ & $>10000$ & $>10000$ & $>10000$ & $>10000$ & $>10000$ & $>10000$ \\
\hline Nb & 3333 & 3454 & 2742 & 2996 & 4872 & 3958 & 3101 & 3395 & 3481 \\
\hline Th & 2370 & 2500 & 1000 & 2700 & 2000 & 2250 & 3000 & 2900 & 2340 \\
\hline $\mathbf{U}$ & 395 & 790 & 200 & 800 & 985 & 1600 & 1475 & 980 & 903 \\
\hline $\mathbf{P b}$ & 147 & 195 & 145 & 230 & 189 & 226 & 174 & 184 & 186 \\
\hline Ga & 110 & 138 & 103 & 158 & 142 & 163 & 128 & 130 & 134 \\
\hline Zn & 3914 & 3863 & 3209 & 4466 & 3987 & 4057 & 3697 & 3751 & 3868 \\
\hline $\mathbf{N i}$ & nd & 9 & 184 & 162 & 119 & 188 & 91 & 173 & 116 \\
\hline $\mathbf{V}$ & 68 & 113 & 63 & 76 & 77 & 91 & 74 & 79 & 80 \\
\hline $\mathrm{Cr}$ & 40 & 34 & 41 & 23 & 36 & 41 & 31 & 33 & 35 \\
\hline $\mathbf{B a} / \mathbf{N b}$ & 1.21 & 1.88 & 1.44 & 1.54 & 0.99 & 1.43 & 1.46 & 1.42 & 1.42 \\
\hline $\mathbf{T h} / \mathbf{U}$ & 6.0 & 3.16 & 5 & 3.38 & 2.03 & 1.41 & 2.03 & 2.96 & 3.25 \\
\hline
\end{tabular}

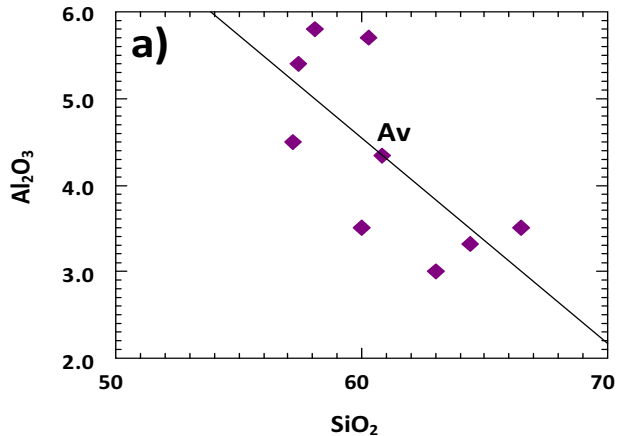

Fig.16: Harker variation diagram for the anomalous quartz vein showing the relation between $\mathrm{SiO}_{2}$ and $\mathrm{Al}_{2} \mathrm{O}_{3}$,

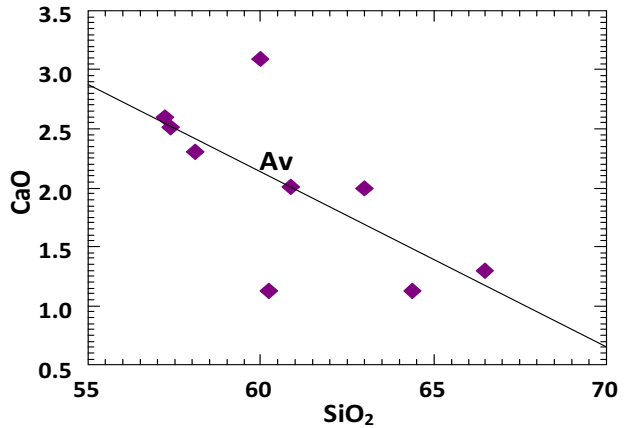

Fig. 17:Harker variation diagram for the anomalous quartz vein showing the relation between $\mathrm{SiO}_{2}$ and $\mathrm{CaO}$ 


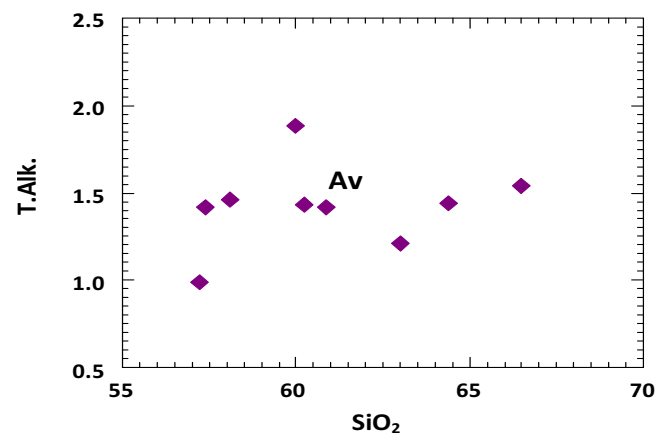

Fig.18:Harker variation diagram for the anomalous quartz vein showing the relation between $\mathrm{SiO}_{2}$ and Total alkalis

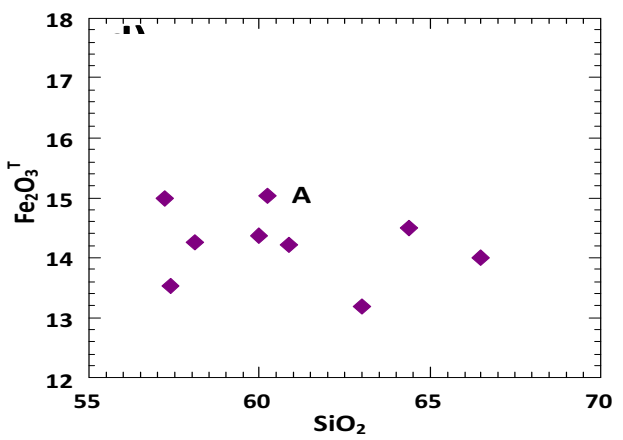

Fig.19:Harker variation diagram for the anomalous quartz vein showing the relation between $\mathrm{SiO}_{2}$ and $\mathrm{Fe}_{2} \mathrm{O}_{3}{ }^{\mathrm{t}}$

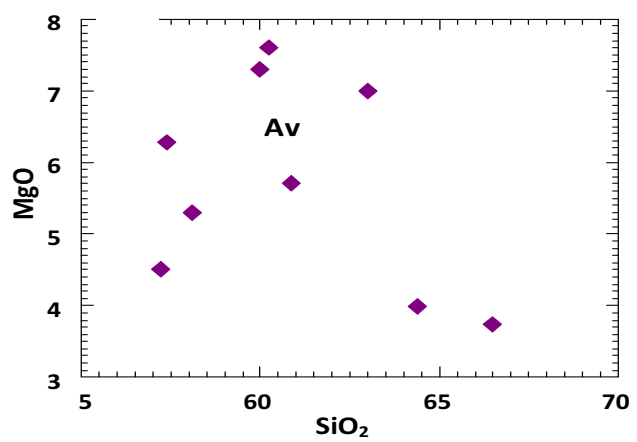

Fig.20:Harker variation diagram for the anomalous quartz vein showing the relation between $\mathrm{SiO}_{2}$ and $\mathrm{MgO}$

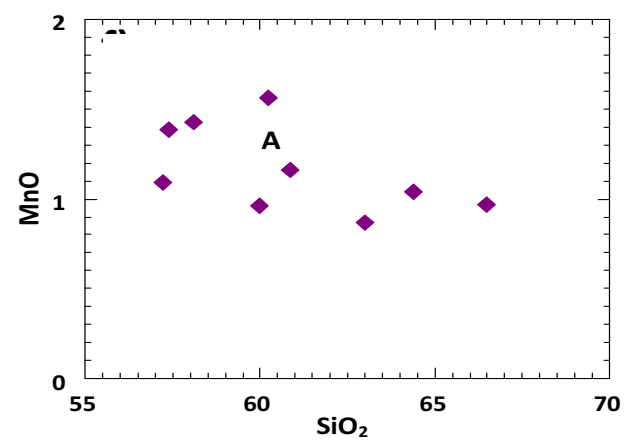

Fig.21:Harker variation diagram for the anomalous quartz vein showing the relation between $\mathrm{SiO}_{2}$ and $\mathrm{MnO}$

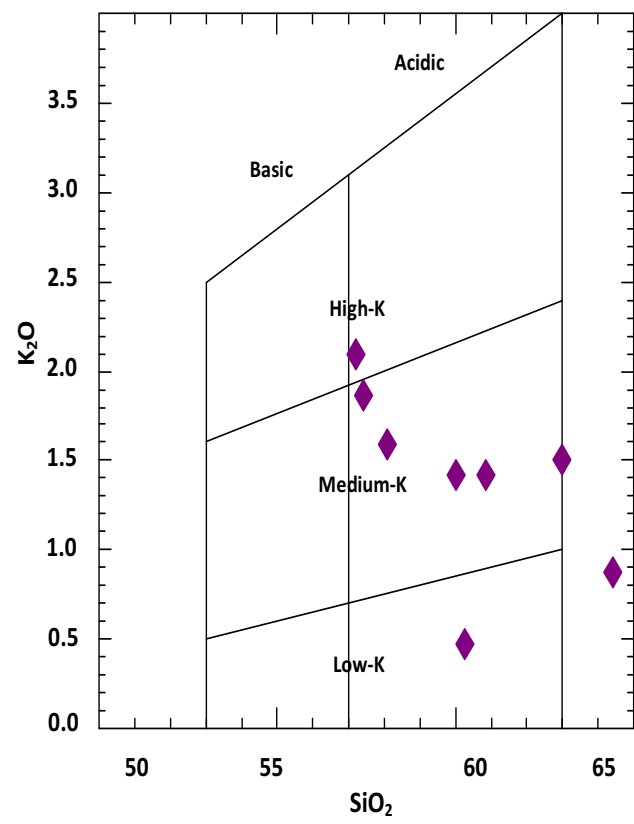

Fig.22: Classification diagram showing acidity and potash content of the anomalous quartz of Wadi Ras Abda (Jill,1981) 


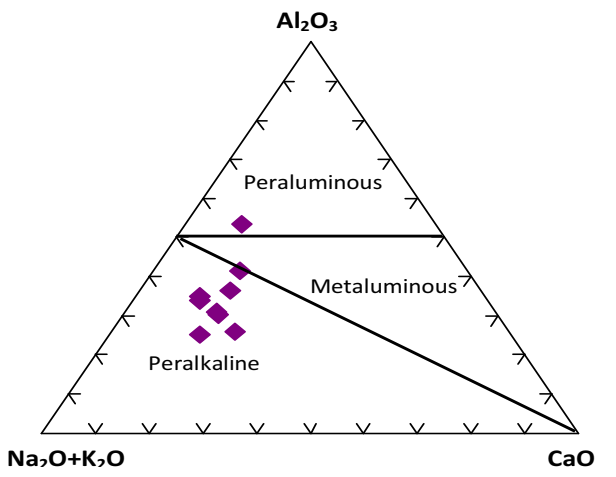

Fig.23:Classification diagram showing alumina saturation and alkalinity of the anomalous quartz vein of Wadi Ras Abda (Petro, 1979)

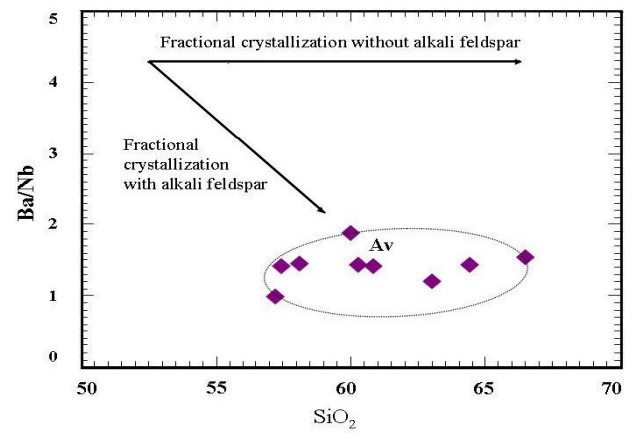

Fig.24: $\mathrm{SiO}_{2}$ vs $\mathrm{Ba} / \mathrm{Nb}$ ratio of the anomalous quartz vein of Wadi Ras Abda diagram of Hubbard et al., (1987)

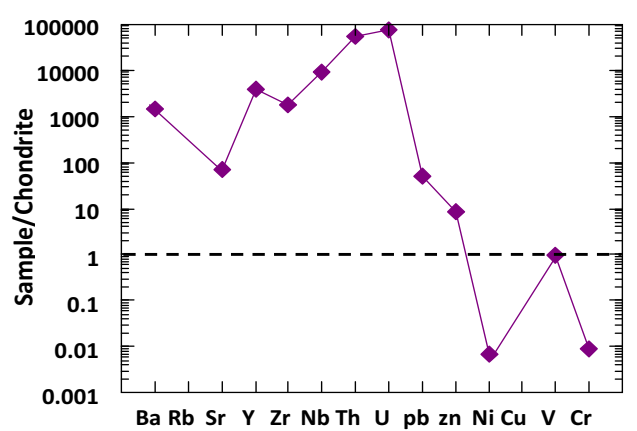

Fig.25: chondrite-normalized trace elements of the anomalous quartz vein of Wadi Ras Abda (Taylor \& McLennan,1985) plotted on the spider diagram showing that the studied rock is characterized by higher REEs concentrations rather than the chondrite concentrations. $\mathrm{Ce}, \mathrm{Nd}, \mathrm{Tb}$ and $\mathrm{Er}$ exhibit positive anomalies. The other elements exhibit negative anomalies (Fig.26).

The ratio $\mathrm{La}_{\mathrm{N}} / \mathrm{Yb}_{\mathrm{N}}$ is considered by Rollinson (1994) as a measure of the degree of fractionation of REEs in the melt. Calculation of this ratio for the rock under consideration showed that the REEs are fractionated with very low degrees (average 0.014, Table2) indicating that they are slightly fractionated in the melt and highly fractionated in the accessory minerals. Plotting of the same ratio versus $\mathrm{Ce}_{\mathrm{N}}$ showed positive relation referring to increasing of the degree of fractionation with increasing of the LREE represented by Ce (Fig.27)

Plotting of Th versus Ce/Th ratio (Fig.28) and $\mathrm{U}$ versus $\mathrm{Ce} / \mathrm{U}$ (Fig.29) exhibit negative relations indicating that the radioelements are not hosted only in the accessory minerals but tend to form their own minerals and/or associated with iron oxides.

\section{RADIOACTIVITY AND MINERALOGY}

The studied rock is highly radioactive (anomalous) with thorium content ranging from 1000 to $3000 \mathrm{ppm}$ with an average 2340 ppm and uranium content ranging from 200 to $1600 \mathrm{ppm}$ with an average $903 \mathrm{ppm}$ (Table1). $\mathrm{Th} / \mathrm{U}$ ratio ranges from 1.41 to 6.0 with an average 3.25 following the magmatic average (3 $-3.5)$ indicating that radioactivity of the rock is syngeneic.

The binary relation of $U$ versus $T h$ is positive with limited scattering and moderate correlation coefficient $(r=0.57)$, (Fig.30) referring to that uranium is tightly related to thorium and in turn, related to the magmatism. On the other hand, similarity of the two patterns of correlation coefficients for $U$ and $T h$ versus the other trace elements (Fig.31) implies some geochemical coherence. The reasonable some 
ABD ELMOEZ A. SADEK et al.

Table 2: Chemical analyses for rare earth elements of the anomalous quartz vein of Wadi Ras Abda

\begin{tabular}{|c|c|c|c|c|c|c|c|c|c|}
\hline Sample No. & R1 & R2 & $\mathbf{R 3}$ & R4 & R5 & R6 & R7 & R8 & Av. \\
\hline \multicolumn{10}{|l|}{ REE(ppm) } \\
\hline La & 48 & 9 & 156 & 12 & ud & 10 & 85 & 9 & 41 \\
\hline $\mathrm{Ce}$ & 871 & 525 & 1653 & 817 & ud & 727 & 745 & 462 & 725 \\
\hline Pr & 149 & 68 & 301 & 110 & ud & 91 & 279 & 94 & 125 \\
\hline Nd & 1898 & 1717 & 3093 & 1630 & 2185 & 2297 & 2112 & 1690 & 1953 \\
\hline Sm & 632 & 44 & 676 & 4 & 656 & & & 518 & 540 \\
\hline Eu & ud & ud & ud & ud & ud & ud & ud & ud & ud \\
\hline Gd & 1325 & 911 & 1314 & 927 & 1434 & 1514 & 1286 & 1065 & 1222 \\
\hline Tb & 465 & 300 & 418 & 325 & 606 & 618 & 404 & 367 & 438 \\
\hline Dy & 2963 & 2048 & 2774 & 2111 & 3375 & 3663 & 2994 & 2463 & 2799 \\
\hline Ho & 711 & 442 & 645 & 481 & 827 & 948 & 702 & 571 & 666 \\
\hline $\mathbf{E r}$ & 10027 & 10436 & 0060 & 9308 & 11167 & 0653 & 10694 & 9947 & 0287 \\
\hline Tm & ud & ud & ud & ud & ud & ud & ud & ud & ud \\
\hline Yb & 2051 & 1648 & 1971 & 1754 & 2356 & 2461 & 2093 & 1875 & 1795 \\
\hline Lu & 372 & 279 & 353 & 303 & 476 & 513 & 375 & 325 & 375 \\
\hline \multicolumn{10}{|c|}{ Geochem.parameters } \\
\hline$\sum \mathbf{L F}$ & 2966 & 2363 & 4879 & 3043 & 2841 & 876 & 3880 & 2773 & 3328 \\
\hline$\sum \mathbf{H} \mathbf{l}$ & 17914 & 16064 & 17535 & 5209 & 20201 & 0370 & 18548 & 6613 & 17807 \\
\hline Tota & 20880 & 18427 & 22414 & 18252 & 23042 & 24246 & 22428 & 19386 & 21134 \\
\hline LRE & 0.166 & 47 & 0.278 & 0.200 & 0.141 & 0.190 & 0.209 & 0.167 & 0.187 \\
\hline $\mathbf{L a}_{N}$ & 130.8 & .52 & 5.07 & 32.7 & 0.1 & 25 & 231.61 & 4.52 & 112.1 \\
\hline $\mathbf{C e}_{\mathrm{N}}$ & 910 & 8.6 & 27.3 & 853.7 & 0.1 & 9.7 & 78.5 & 482.8 & 757.8 \\
\hline $\mathbf{Y} \mathbf{b}_{\mathbf{N}}$ & 854.8 & 686.7 & 8212.5 & 7308.3 & 816.2 & 10254.2 & 8720.8 & 7812.5 & 8442.1 \\
\hline & 15 & & 0.052 & 0.004 & 0.1 & 0.003 & 0.027 & 0.003 & 0.014 \\
\hline $\mathrm{Ce} /$ & 0.367 & & 16.53 & & 0.1 & & & 0.159 & 0.408 \\
\hline $\mathrm{Ce} / \mathrm{U}$ & 2.21 & 0.665 & 8.265 & 1.021 & 0. & 0.454 & 0.505 & 0.471 & 1.69 \\
\hline
\end{tabular}

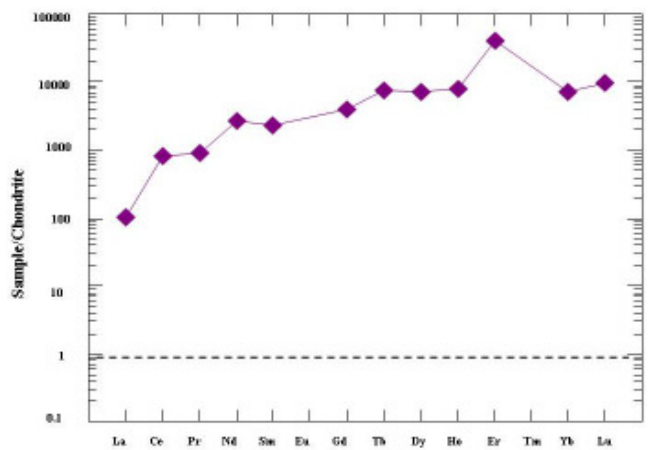

Fig.26: Pattern of chondrite-normalized REEs of the anomalous quartz vein of Wadi Ras Abda (Taylor and McLennan, 1985)

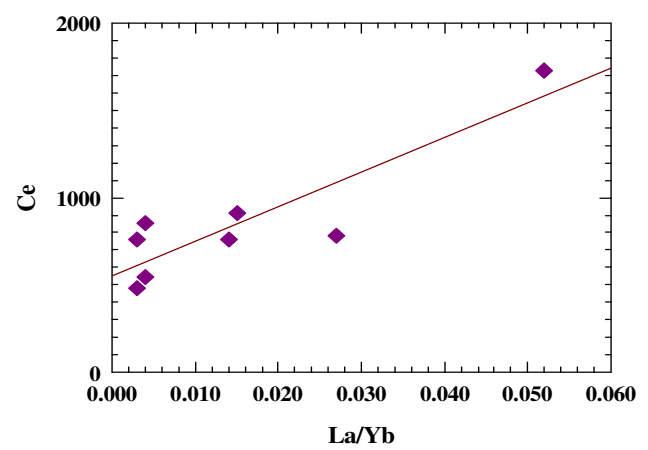

Fig.27: Degree of fractionation vs $\mathrm{Ce}_{\mathrm{N}}$ of the anomalous quartz vein 


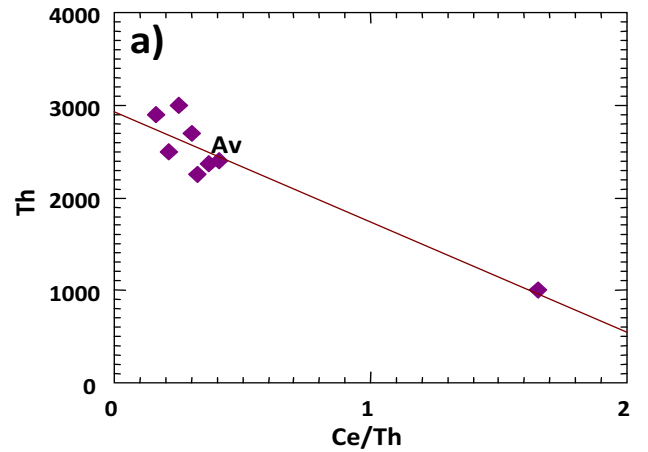

Fig.28: Binary diagram of Th vs $\mathrm{Ce} / \mathrm{Th}$ ratio for the anomalous quartz vein

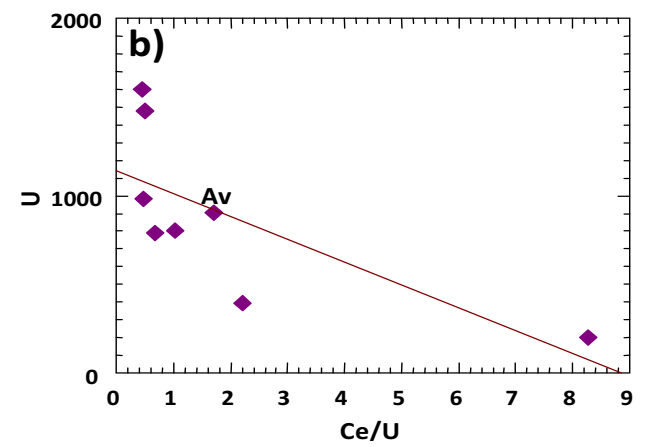

Fig.29: Binary diagram of U vs Ce/U ratio for the anomalous quartz vein Wadi Ras Abda

values of correlation coefficients ranging from ( 0.54 for U-Y, 0.61 for U- pb, 0.57 for U- Th, 0.55 for $\mathrm{Th}-\mathrm{Zn}$ and -0.62 for $\mathrm{Th}-\mathrm{Cr}$ ) (Table 3 ) suggesting that the evolution of igneous liquid is single-stage process and the role of epigenetic processes is limited.

The mineralogical study of the heavy minerals separated from the studied rock using heavy liquid separation Bromoform $\left(2.89 \mathrm{~cm}^{3}\right)$ revealed that the presence of zircon, thorite, uranothorite and $\mathrm{Nb}$ - $\mathrm{Ta}$ minerals are the main radioactive minerals. They are intensively metamictized due to presence of the radioelements in their crystal lattices as indicated by the EDX-analyses. The radioelements form

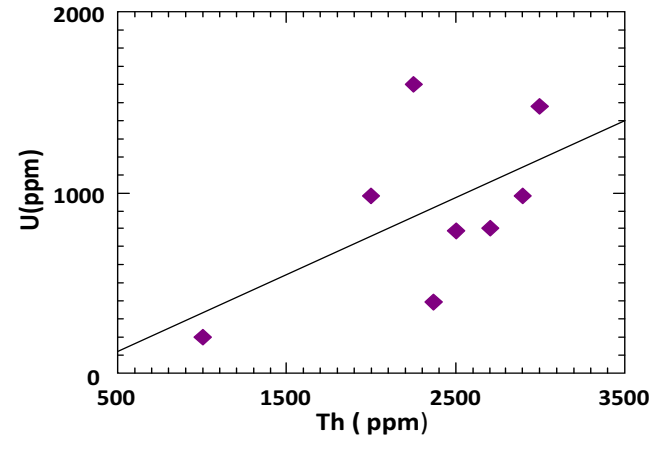

Fig.30:Binary relation of $\mathrm{U}$ vs $\mathrm{Th}$ of the anomalous quartz vein of Ras Abda

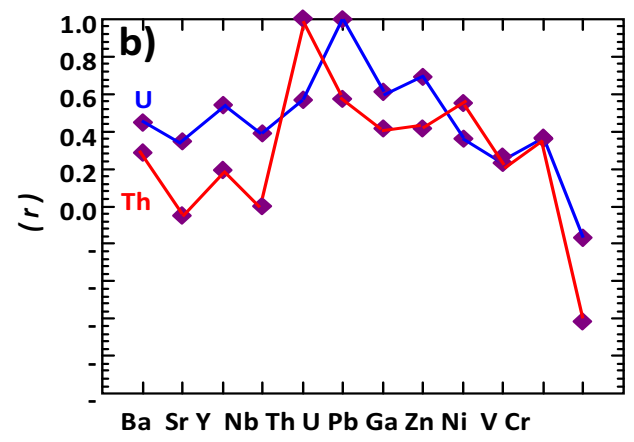

Fig.31:Correlation coefficients patterns of $U$ and $T h$ vs trace elements of the anomalous rock of Ras Abda (Rollinson, 1993)

their own minerals associated with zircon and $\mathrm{Nb}$-minerals as minute inclusions, overgrowths or as defect structure filling the $A$ - or $B$-sites.

\section{Zircon $\left(\mathrm{ZrSiO}_{4}\right)$}

It occurs as prismatic crystals of tetragonal system with variable lengths for the c-axes. The first type is characterized by long c-axis (Fig.32), while the second type is characterized by shorter c-axis and less c/a ratio about 1.3 (Fig.33); the third type has the shortest prismatic face and the shortest c-axis with $\mathrm{c} / \mathrm{a}$ ratio less than the unity $(<1)$ (Fig.34). It is easily recognized by XRD technique (Fig.35). 
Table 3: Correlation coefficients of $U$ and $T h$ Vs trace elements for the anomalous rock

\begin{tabular}{|c|c|c|}
\hline Element & $\mathbf{U}(\boldsymbol{r})$ & Th (r) \\
\hline Ba & 0.45 & 0.28 \\
\hline $\mathbf{S r}$ & 0.35 & -0.05 \\
\hline $\mathbf{Y}$ & 0.54 & 0.19 \\
\hline $\mathbf{N b}$ & 0.39 & 0.0 \\
\hline Th & 0.57 & 1.0 \\
\hline $\mathbf{U}$ & 1.0 & 0.57 \\
\hline Pb & 0.61 & 0.41 \\
\hline Ga & 0.69 & 0.41 \\
\hline $\mathbf{Z n}$ & 0.35 & 0.55 \\
\hline $\mathbf{N i}$ & 0.23 & -0.26 \\
\hline $\mathbf{V}$ & 0.36 & 0.31 \\
\hline $\mathbf{C r}$ & -0.17 & -0.62 \\
\hline
\end{tabular}

Zircon is present as individual or twinned crystals showing sometimes parallel twining (Fig.32); and its composition is confirmed by ESEM. Some crystals are characterized by overgrowths or inclusions of uranothorite (Fig.36); showing coexistence of $\mathrm{Hf}, \mathrm{U}$, and Y (Fig.37).

\section{Thorite $\left(\mathrm{ThSiO}_{4}\right)$}

Is a common radioactive mineral occasionally; it is found as isomorphous with zircon and occurs in the same crystal habits. In thin section thorite occurred as riddich-orange inclusions enclosed in both partially or completely metamictized zircon and polycrase confirmed by The ESEM techniques. EDX analysis shows that thorite is composed mainly of Th

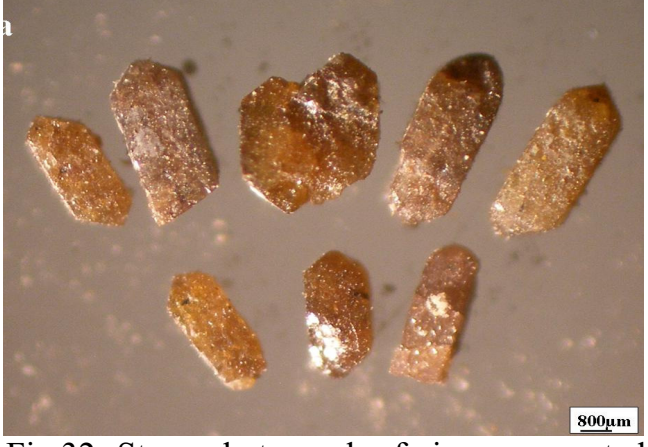

Fig.32: Stereophotograph of zircon separated from the anomalous rock of Wadi Ras Abda.,long prismatic zircon crystals.

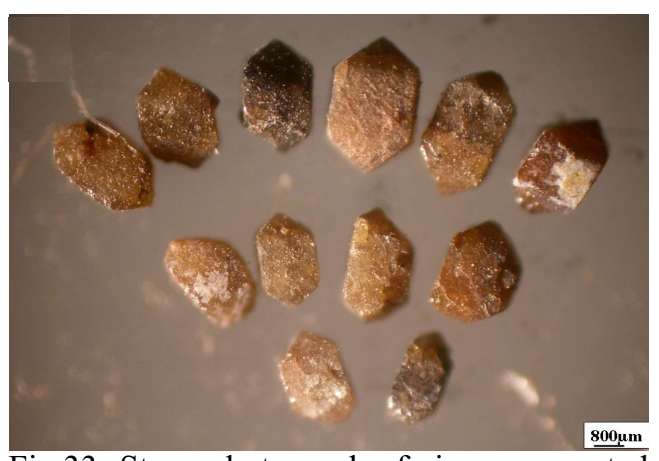

Fig.33: Stereophotograph of zircon separated from the anomalous rock of Wadi Ras Abda, Medium prismatic zircon crystals

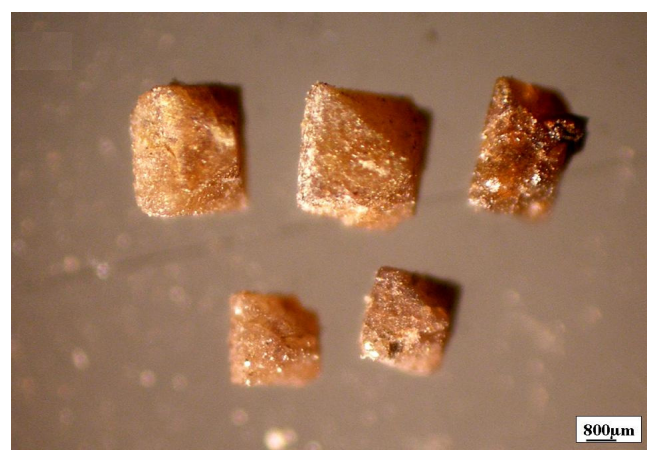

Fig.34: Stereophotograph of zircon separated from the anomalous rock of Wadi Ras Abda.,Short prismatic zircon crystals. 


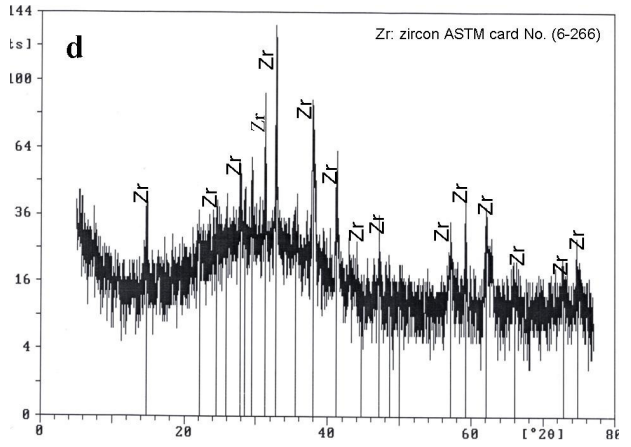

Fig.35: XRD diffractogram of zircon

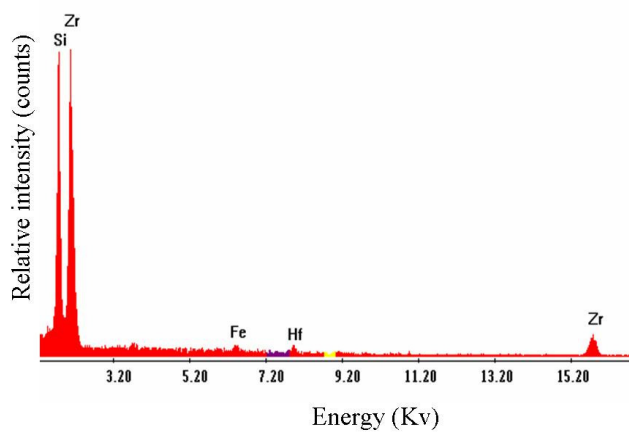

Fig.36:EDX of Zircon from the anomalous quartz vein of Wadi Ras Abda

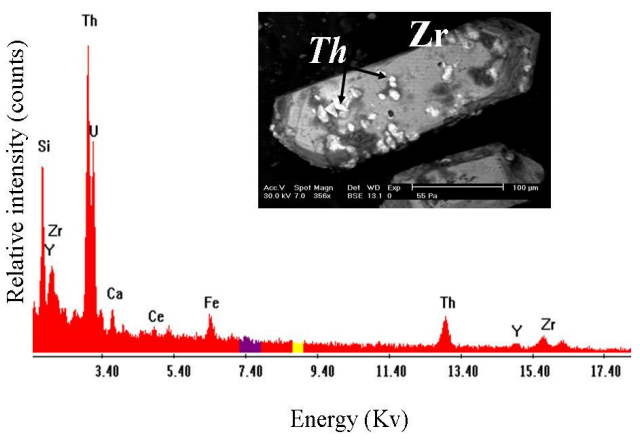

Fig.37:BSE image and EDX inclusions of uranothorite $(\mathrm{Th})$ in zircon $(\mathrm{Zr})$ crystal
(65 wt \%), Si (15 wt \%) Al (8 wt\%) and $\mathrm{Ca}$, with small to minor amounts of $\mathrm{U}$ about $(9 \mathrm{wt}$ \%), (Fig.38)

\section{Uranothorite (U,Th) $\mathrm{SiO}_{4}$}

Thorium tends to form its own mineral as uranothorite; it is occasionally recorded as bright inclusions in zircon (Fig.39), or found as prismatic crystals of uranothorite it is confirmed by ESEM. The EDX analysis indicates that it consists essentially of $\mathrm{ThO}_{2}$, $\mathrm{SiO}_{2}$ and significant amount of $\mathrm{UO}_{2}$ reaching up to $7 \%$. Heinrich (1958) suggested that, uranium is usually present in amount up to $10 \%$ in uranothorite. Other elements present in small to minor amounts such as $\mathrm{Ca}, \mathrm{Al}, \mathrm{Zr}$ and Fe (Fig. 40).

\section{Nb-Ta Minerals}

The columbite-tantalite mineral group is the most important family of Nb-Ta minerals (Cerny and Erict, 1989; Suwimonprccha, et al. 1995). $\mathrm{Nb}$ and Ta occur mostly together as complex oxides or hydroxides, rarely as silicates in different rock types. In the studied rocks these minerals are easily separated by heavy liquid separation. It is found as fractured black to dark brown color, medium to fine, suhedral crystals and submetalic luster (Fig.41). The columbite was identified by

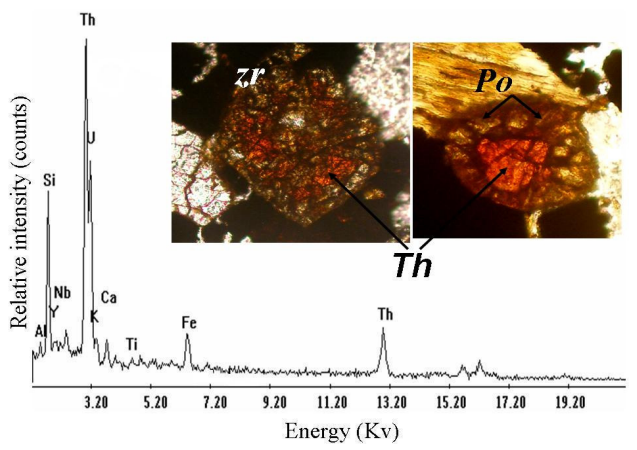

Fig. 38: EDX and Photomicrograph of thorite (Th) inclusion in zircon and uranopolycrase crystal $(\mathrm{Po})$. 


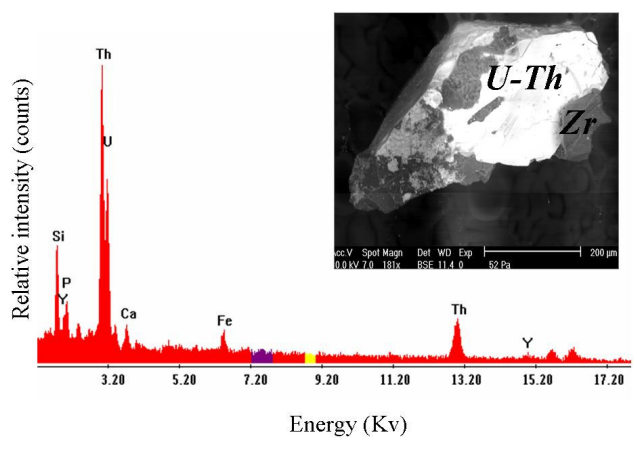

Fig.39: BSE image and EDX of uranothorite inclusion from anomalous quartz vein

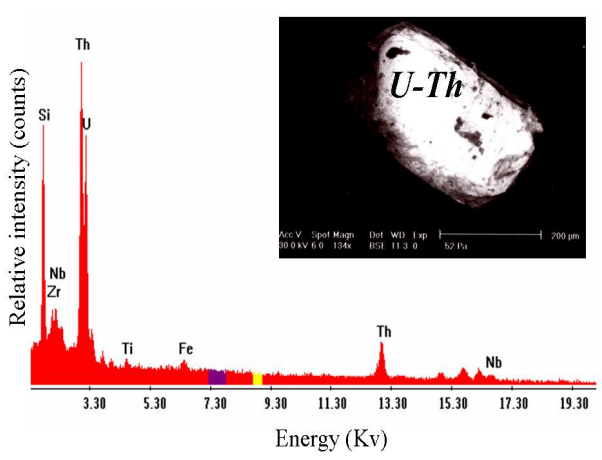

Fig. 40: BSE image and EDX of uranothorite from anomalous quartz vein

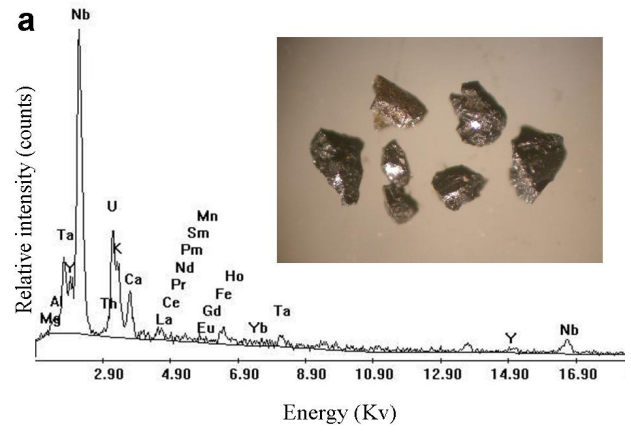

Fig.41:Stereophotograph and EDX of columbite from anomalous rock using ESEM analyses it is distinctly enriched in $\mathrm{Nb}, \mathrm{Ta}, \mathrm{K}, \mathrm{Ca}, \mathrm{Al}$, and REE (Fig.41) confirmed by XRD-diffractogram (Fig.42). The relatively high $U$ contents in the studied columbite suggest the presence of $U$ in the lattice of these minerals.

\section{Euxenite -Polycrase Series}

This series is the second rare earth-bearing mineral groups which have been separated from the studied anomalous quartz vein. Chemically euxenite-polycrase series is considered an oxide or tantalite-columbite of the type $A B_{2} O_{6}$. With $A=\mathrm{Y}, \mathrm{Ca}, \mathrm{Ce}, \mathrm{U}, \mathrm{Th} ; B=$ $\mathrm{Nb}, \mathrm{Ta}, \mathrm{Ti}, \mathrm{Fe}^{3+}$. The predominant constituents are $\mathrm{Y}, \mathrm{Ca}, \mathrm{Ti}$ and Ta. The high Ti end of the series is called polycrase (Y,Ca,Ce,U,Th) $(\mathrm{Ti}, \mathrm{Nb}, \mathrm{Ta},)_{2} \mathrm{O}_{6}$ and the high Ta member is euxenite (Y,Ca,Ce,U,Th)(Nb,Ta,Ti) $\mathrm{O}_{6}$ which in some cases contains up to $9 \% \mathrm{Al}_{2} \mathrm{O}_{3}$ and more than $21 \% \mathrm{SiO}_{2}$ (Dana, 1963). In the studied rock euxenite occurs as very small anhedral disseminated prismatic grains, characterized by brownish color with resinous luster and are commonly metamict and patched by these crystals are identified by ESEM (EDX) analyses (Fig.43). The EDX analysis indicates that euxenite is composed essentially of $\mathrm{Nb} 47 \%$, Y $13 \%$, U $10 \%$, Th $6 \%$, Si $11 \%$, Al $6 \%$ and REEs about $5 \%$. The high contents of $U$ and $\mathrm{Th}$ in these minerals indicate their strong radioactive nature (Fig.44).

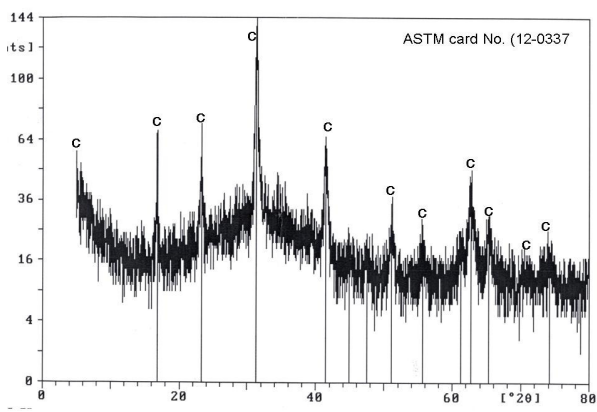

Fig.42:XRD-diffractogram of the columbite 
MINERALOGY, CHEMISTRY AND RADIOACTIVITY OF THE ANOMALOUS 93

Most of the separated minerals microscopically are described as orthorhombic crystals with bipyramidal form and translucent brown red color identified by ESEM/EDX analyses as polycrase (Fig.45). It is intensively metamictized and difficult to be recognized by XRD; recognition had been reached after heating of the picked crystals for three hours at temperature $950^{\circ} \mathrm{C}$ giving the characteristic diffractogram of euxenite (Fig.46) as a polymorph of polycrase. It is also present as intergrowth with zircon where its composition is identified by ESEM (Figs.47\&48). It is clarifying that euxenite is radioactive, typified as uranopolycrase and considered as good collector for the rare earth elements (Fig.49).

$\mathrm{Nb}$-Ta-Ti minerals are susceptible to radiation damage because their compositions are characterized by extensive isomorphous substitution for calcium in the A-site as following:

$\mathrm{U}^{4+} \rightarrow 2\left(\mathrm{Ca}^{2+}\right)$ and $2\left(\mathrm{REE}^{3+}\right) \rightarrow 3\left(\mathrm{Ca}^{2+}\right)$---- (Ewing 1975)

Hence $3 \mathrm{U}^{4+}$ and/ or $4\left(\mathrm{REE}^{3+}\right)$ may substitute $6\left(\mathrm{Ca}^{2+}\right)$ interpreting the ever coherence of uranium and $\mathrm{REE}$ in the Nb-Ta-Ti minerals.

In the experimental work of Tomašić et al., (2004), they studied the influence of heat on the metamict polycrase where it was heated at temperature ranging from $400^{\circ} \mathrm{C}$ to $1000^{\circ} \mathrm{C}$ for 24 hours; such a heat treatment can induce the recrystallization of radiation-damaged structure. He reported that polycrase started to transform to euxenite structure at $650^{\circ} \mathrm{C}$.

Graham and Thornber (1974b) have proposed a mechanism of metamictization in complex Nb-Ta-Ti oxides and considered that the metamict state is not only due to radiation damage, but properly to their complex chemical composition that makes their structure susceptible to the radiation damage. They attributed the metamictization to a process named as "self-annealing" caused by the energy of alpha particles that dissipates in the form of heat resulting in a thermal spike reaching temperatures of $10^{4} \mathrm{k}$ for periods of $10^{-11}$.

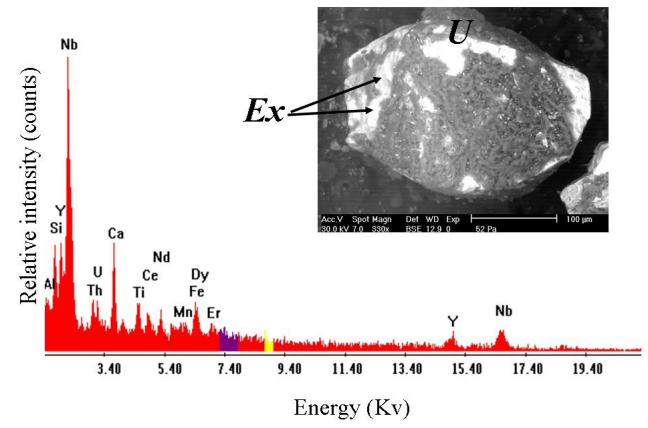

Fig.43:BSE image and EDX of Euxenite (Ex) from quartz vein of Wadi Ras Abda

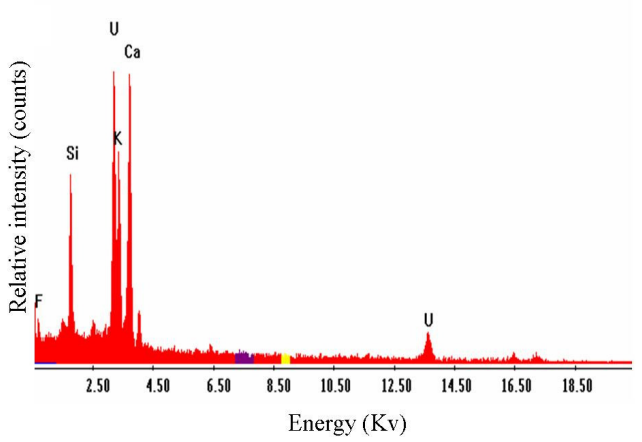

Fig.44:BSE image and EDX of uranophane inclusions (U)

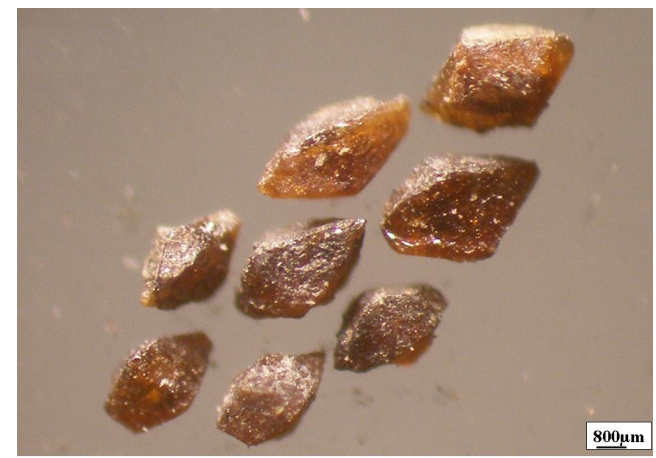

Fig.45:Stereophotograph of uranopolycrase from the anomalous quartz vein 


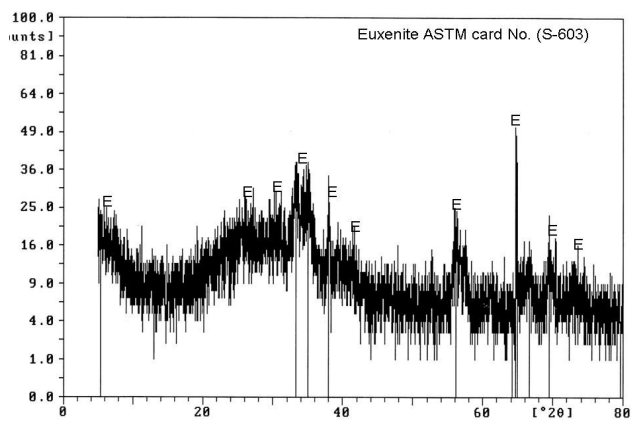

Fig.46:XRD-diffractogram of Euxenite after heating of the uranopolycrase $\left(950^{\circ} \mathrm{C}\right)$

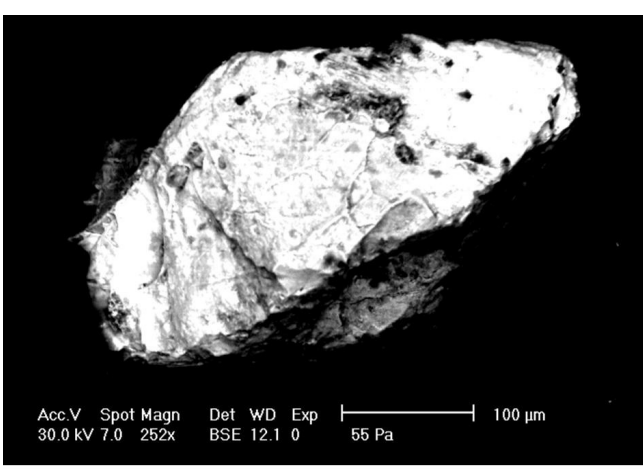

Fig.47:BSE image of uranopolycrase

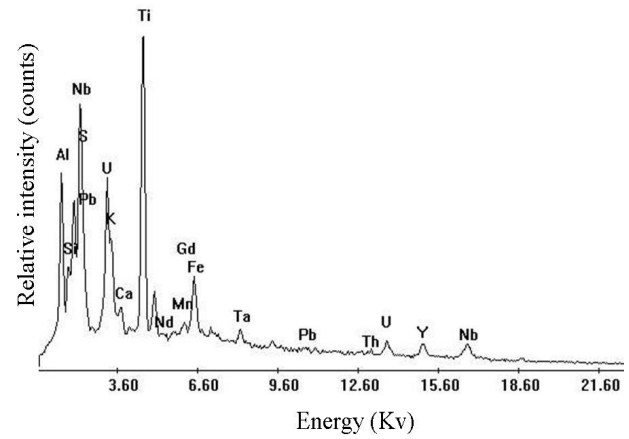

Fig.48:EDX of uranopolycrase

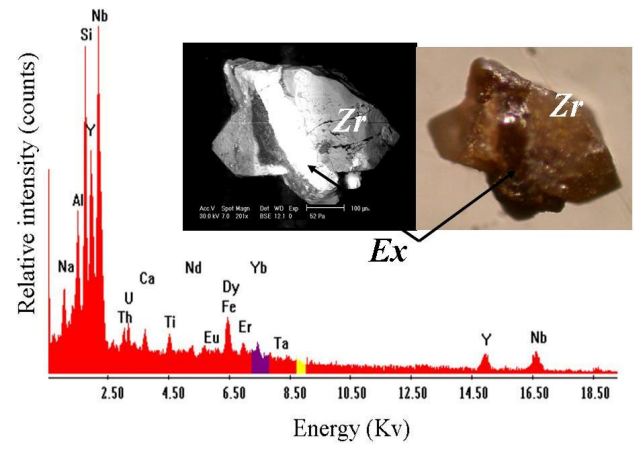

Fig.49:Stereophotograph, BSE image and EDX of euxenite intergrowth with zircon from the anomalous quartz vein of W. Ras Abda

Ewing, (1975) argued that the process of annealing leads to four probable new states: a) glass state, b) the original phase with new lattice (disordering), c) fine crystalline oxides (recrystallization) or d) annealing (metamectization).

\section{DISCUSSION AND CONCLUSION}

The studied rock composed mainly of quartz with fragments from the wall rock containing high percentage of accessory minerals beside the iron oxides and possesses some clues enhancing the opinion that this rock originated from new silicic magma.

1-The studied rock cutting the granodiorite of Ras Abda leads to the concept that process of differentiation have been ceased after the granodiorite, a new magma (silicic) evolved from the the parent magma (calc-alkaline) and ascended along the shearing plane followed by in-suite consolidation. Temperature-pressure releasing caused by shearing is the main factor for stopping of the differentiation.

2-This rock maintains the proper characteristics of an evolved magma-high contents of iron and magnesium oxides enhanced by the black color of the rock and dominance of opaque in thin sections referring to stopping of fractionation for the ferromagnesian minerals 
MINERALOGY, CHEMISTRY AND RADIOACTIVITY OF THE ANOMALOUS 95

in the earlier stages followed by ceasing of differentiation, EDX analysis proved that these opaque are chemical complexes of $\mathrm{K}-\mathrm{Na}-\mathrm{Ca}$ Mg-Fe oxides.

-high concentration of the trace elements and REEs (comprising uranium and thorium) enhanced by presence of enormous of the accessory minerals (uranopolycrase, uranothorite and zircon).

-complete absence of any feldspars enhanced by undetected concentration of Eu referring removal of plagioclase, also undetected $\mathrm{Rb}$ referring to removal of potash feldspars accompanied with the low content of aluminum (4.34 ppm) indicated that the feldspars fractionated in the earlier stage of differentiation (gabbro-granodiorite).

-the measurable grain size of rock $(=1.2$ $\mathrm{mm})$ larger than the volcanic grain size $(>0.5$ $\mathrm{mm}$ ) eliminating the probability of vulcanicity or vetrification.

From the above remarks it is concluded that the studied rock is an acidic rock characterized by low aluminum and medium potassium contents with peralkaline affinity radioelement (Th and $\mathrm{U}$ ) and high concentration of REEs specially the HREEs with very low degree of fractionation in the melt (0.014).

The trace element and REEs accommodate to the accessory minerals that recognized by XRD and ESEM as zircon, uranothorite and $\mathrm{Nb}$-minerals (columbite, euxenite and uranopolycrase) the radio elements from their own minerals as separate crystals uranothorite and as minute inclusions overgrowths or defect structure filling the A- or B-sites associating zircon and $\mathrm{Nb}$-minerals.

The event of sharing plays an important role in releasing the heat and the pressure necessary for the process of differentiation caused stopping for the process and the shearing plane considered as outlet for the magma to ascend.

The author favors to consider the process of heating that applied for metamict mineral (uranopolycrase in the present work) as an in- ferred process for the process of self-annealing of Graham and Thornber, (1974b) and agreed with the experimental work of Tomasic et al., (2004).

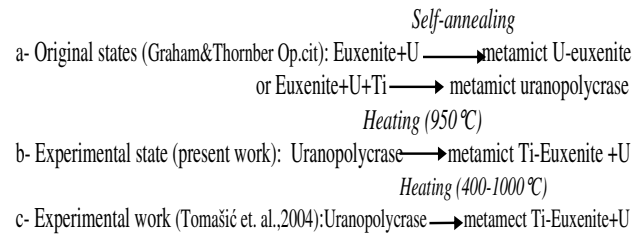

The author considered the third and fourth states of Ewing (1975) (recrystalisation and metamictaization by annealing) as the main state for recrystalization of the U-bearing minerals (U-euxenite and uranopolycrase) in this work. He also agreed with the opinon of Ewing for the interpretation of geochemical coherence between uranium and REEs, as controlled by the isomorphism substitution of both of them for the calcium cations in the Asite of $\mathrm{Nb}-\mathrm{Ta}-\mathrm{Ti}$ minerals.

\section{Acknowledgements}

The authors are very grateful to Prof. Dr Ashraf El Azab (NMA) for his field facilities and great thanks to our collogues in the Scanning Electron Microscope Lab (NMA).

\section{REFERENCES}

Bowen, N.L., 1928. The evolution of the igneous rocks. Princeton Univ. Press.

Černy', P. and Ercit, T.S., 1989. Mineralogy of niobium and tantalum: crystal chemical relationships, paragenetic aspects and their economic implications. In: Lanthanides, Tantalum and Niobium (Moller, P.; Černy', P. and Saupe, F.,Eds.), 2779.

Dana, E.S., 1963. A textbook of mineralogy, John Wiley and Sons. Inc., New York and London, $851 \mathrm{p}$.

El Hadary, A.F; Soliman, A.A., and Omran, A.A., 2015. Contributions to the geology and mineralogy of Wadi Ras Abda area, North Eastern Desert, Egypt. NSS J. , 4, 47-59. 
Ewing, R.C. 1975. The Crystal Chemistry of Complex Niobium and Tantalum Oxides. IV. The Metamict State: Discussion Amer. Mineralogist, Depart. Geol., Univ. New Mexico, 60, 728-733.

Graham, R. J., and Thornber M. R., 1974b. The crystal chemistry of complex niobium and tantalum oxides. Structural classification of MO, phases. Am. Mineral. 59, 1026-1039.

Greenberg, J.K., 1981. Characteristics and origin of the Egyptian younger granites summary. Bull. Geol. Soc. Amer. Part1, 92, 224-232.

Hassan, M.A., and Hashad, A.H., 1990. Precambrian of Egypt. The geology of Egypt. Edited by Rushdi Said. published by A.A.Balkema /Rotterdam,201-245.

Heinrich, E.W., 1958: Mineralogy and geology of radioactive raw materials. McGraw Hill Book Company, New York.

Hubbard, H. B.; Wood, L. F., and Rogers, J. J. 1987. Possible hydration anomaly in the upper mantle prior to Red Sea rifting: Evidence from petrologic modeling of the W. Natash alkali basalt sequence of eastern Egypt. Geol. Soc. Amer. Bull., 98, 92-98.

Jill, D. P., 1981. Mantle Metasomatism and alkaline Magmatism. Geol. Soc. Amer., P.O Box 9140, Boulder, Colorado, 80301.

Marchizinco, Z., 1986. separation and spectrophotometer Determination of element. New York, Harwood, John Wiley and sons, Inc.

Mathew, K J.; Burgers, Ogts, S.V.; Mason, P. M , and Narayanan, U.I., 2009. uranium assay de- termination using Davies Gray titration an over view and implementation of Gun for uncertainty evaluation. Proc. English Inter. Conf. methods and applications of ratio analytical chemistry (Marcvii) Kailua-Kona, Hawaii, S- 10 .

O'Hara, M.J., 1980. Nonlinear nature of the unavoidable long-lived isotopic, trace and major element contamination of a developing magma chamber. Phil. Trans. R. Sec., 297, 215-227.

Petro, W.L.; Vogel, T.A., and Wilband, J.T., 1979. Major element chemistry of plutonic rock suites from compressional and extensional plate boundaries. Chem. Geol., 26, 217-235.

Rollinson, H.R., 1993. Using geochemical data: evaluation, presentation, and interpretation, Longman Scientific \& Technical, Singapore. 352p.

Shapiro, L., and Brannock, W.W., 1962. Rapid analysis of silicate, carbonate and phosphate rocks. U. S. Geol. Surv. Bull, 1114-A.

Suwimonprecha, P.; Černy', P., and Frieddrich, G., 1995. Rare metal mineralization related to granites and pegmatites, Phuket, Thailand. Econ. Geol., 90, 603-15.

Taylor, S.R., and McLennan S.M., 1985. The continental crust; its composition and evolution. Blackwell, Scientific Oxford.

Tomašič, N.; Gajovič, A.; Bermanec, V., and Rajič, M., 2004. Recrystallization of metamict $\mathrm{Nb}-$ Ta-Ti-REE complex oxides: a coupled X-raydiffraction and Raman spectroscopy study of aeschynite-(Y) and polycrase-(Y). Amer. Mineralogist. 42, 1847-1857. 


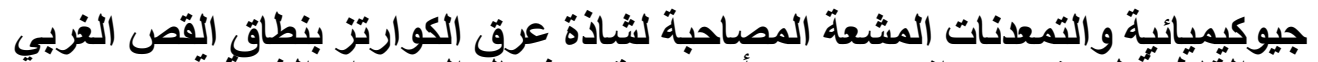

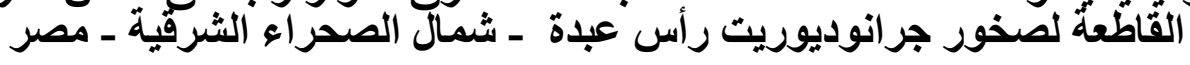

$$
\text { عبد المعز على صـادق ، وفاء حسنى صالح و ايهاب قرنى ابوزيد }
$$

تتناول الدراسة عرق الكوارتز بمنطقة القص الغربية القاطعة لصخر الجر انوديوريت و التىى

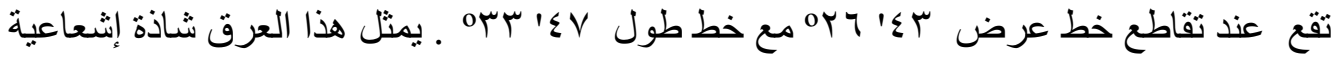

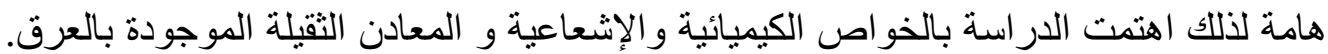

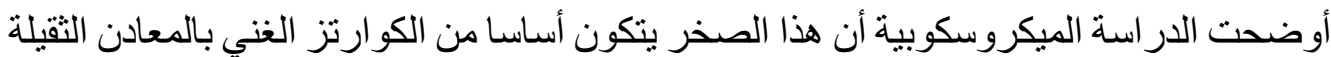

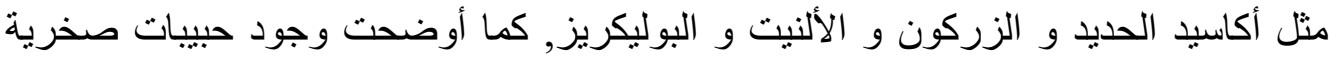

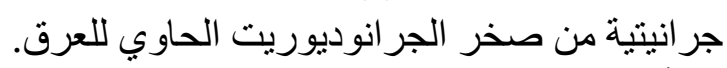

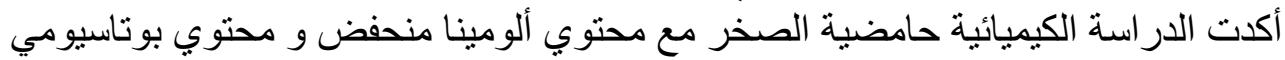

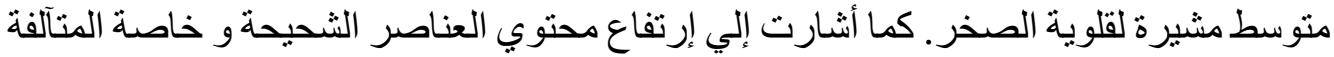

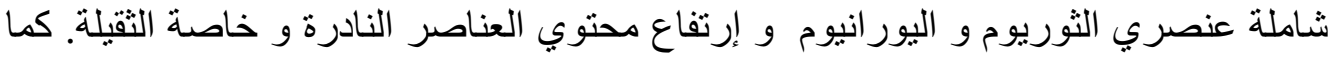

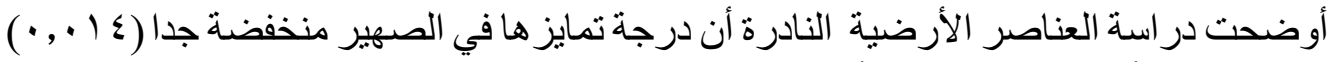

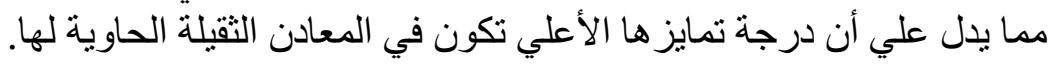

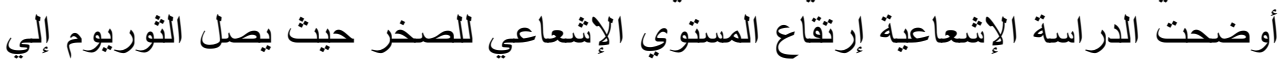

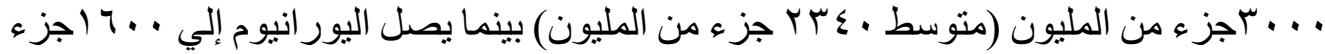

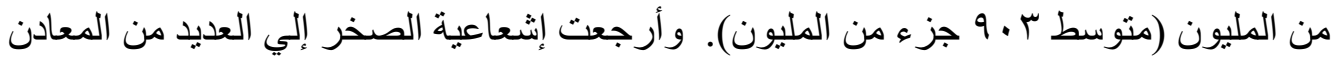

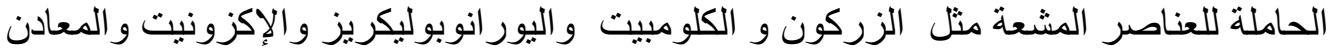

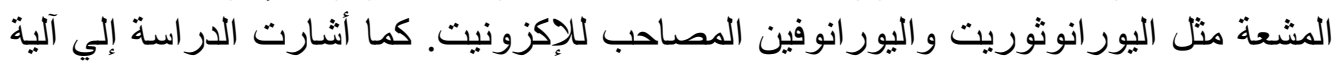

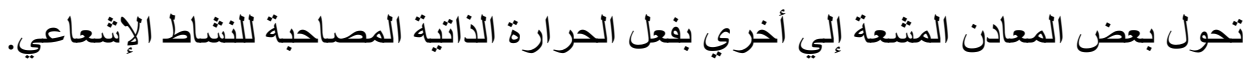

